\title{
The crucial role of roots in increased cadmium-tolerance and Cd-accumulation in the pea mutant $S G E C d^{t}$
}

\author{
A.A. BELIMOV ${ }^{1 *}$, N.V. MALKOV ${ }^{1}$, J.V. PUHALSKY ${ }^{1}$, V.E. TSYGANOV ${ }^{1}$, K.B. BODYAGINA ${ }^{1,2}$ \\ V.I. SAFRONOVA ${ }^{1}$, K.-J. DIETZ ${ }^{3}$, and I.A. TIKHONOVICH ${ }^{1,2}$ \\ All-Russia Research Institute for Agricultural Microbiology, Pushkin, 196608, St.-Petersburg, Russia ${ }^{1}$ \\ Saint-Petersburg State University, 199034, St.-Petersburg, Russia ${ }^{2}$ \\ Bielefeld University, D-33501, Bielefeld, Germany ${ }^{3}$
}

\begin{abstract}
Elucidation of mechanisms underlying plant tolerance to cadmium, a widespread toxic soil pollutant, and accumulation of Cd in plants are urgent tasks. For this purposes, the pea (Pisum sativum L.) mutant $S G E C d^{t}$ (obtained by treatment of the laboratory pea line SGE with ethylmethane sulfonate) was reciprocally grafted with the parental line SGE, and four scion/rootstock combinations were obtained: SGE/SGE, $S G E C d^{t} / S G E C d^{t}$, SGE/SGECd $d^{t}$, and $S G E C d^{t} / \mathrm{SGE}$. They were grown in hydroponics in the presence of $1 \mu \mathrm{M} \mathrm{CdCl}_{2}$ for $30 \mathrm{~d}$. The SGE and $S G E C d^{t}$ scions on the $S G E C d^{t}$ rootstock had a higher root and shoot biomass and an elevated root and shoot Cd content compared with the grafts having SGE rootstock. Only the grafts with the SGE rootstock showed chlorosis and roots demonstrating symptoms of Cd toxicity. The content of nutrient elements in roots $\left(\mathrm{Fe}, \mathrm{K}, \mathrm{Mg}, \mathrm{Mn}, \mathrm{Na}, \mathrm{P}\right.$, and $\mathrm{Zn}$ ) was higher in the grafts having the $S G E C d^{t}$ rootstock, and three elements, namely $\mathrm{Ca}, \mathrm{Fe}$, and $\mathrm{Mn}$, were efficiently transported by the $S G E C d^{t}$ root to the shoot of these grafts. The content of other measured elements $(\mathrm{K}, \mathrm{Mg}, \mathrm{Na}, \mathrm{P}$, and $\mathrm{Zn})$ was similar in the root and shoot in all the grafts. Then, the non-grafted plants were grown in the presence of $\mathrm{Cd}$ and subjected to deficit or excess concentrations of $\mathrm{Ca}, \mathrm{Fe}$, or Mn. Exclusion of these elements from the nutrient solution retained or increased differences between SGE and $S G E C d^{t}$ in growth response to $\mathrm{Cd}$ toxicity, whereas excess of $\mathrm{Ca}, \mathrm{Fe}$, or $\mathrm{Mn}$ decreased or eliminated such differences. The obtained results assign a principal role of roots to realizing the increased Cd-tolerance and $\mathrm{Cd}-$ accumulation in the $S G E C d^{t}$ mutant. Efficient translocation of $\mathrm{Ca}, \mathrm{Fe}$, and $\mathrm{Mn}$ from roots to shoots appeared to counteract $\mathrm{Cd}$ toxicity, although $\mathrm{Cd}$ was actively taken up by roots and accumulated in shoots.
\end{abstract}

Additional key words: calcium, grafting, heavy metals, iron, magnesium, manganese, phosphorus, potassium, sodium, zinc.

\section{Introduction}

Cadmium (Cd) is a widespread soil pollutant and often accumulates in plants including agricultural crops. It has a high cellular toxicity, which can be deleterious not only to plants but also to animals and humans. Plants evolved a number of biochemical mechanisms to minimize $\mathrm{Cd}$ penetration and accumulation, in particular in the symplast, and to cope with $\mathrm{Cd}$ inside tissues (Sanita di Toppi and Gabrielli 1999, Dong et al. 2007, Hasan et al. 2009, Verkleij et al. 2009, Kulaeva and Tsyganov 2011, Lin and Aarts 2012). These and other studies identified a root, which is in the closest contact to soil-borne $\mathrm{Cd}$, as a plant organ being most vulnerable to $\mathrm{Cd}$ toxicity. Efficient subcellular compartmentation and loading into the xylem for transport to the shoot are essential features of metal tolerance in whole plants.

Mechanisms of $\mathrm{Cd}$ tolerance and safe accumulation were revealed by using plant mutants having alterations in related traits and by exploiting a natural variation of tolerance. The role of phytochelatins in $\mathrm{Cd}$ detoxification was unraveled with Cd-sensitive Arabidopsis thaliana mutants, such as cad2, deficient in $\gamma$-glutamylcysteine synthetase and thus in phytochelatin synthesis (Howden

Submitted 12 August 2017, last revision 15 November 2017, accepted 13 December 2017.

Abbreviation: GSH - glutathione.

Acknowledgements: The work on establishing appropriate $\mathrm{Cd}$ concentration for grafting experiments was supported by the International Association for the Promotion of Co-operation with Scientists from the New Independent States of the former Soviet Union (grant No. 01-2170). The work on plant growth and heavy metal content in plants was supported by the Russian Foundation of Basic Research (grant Nos. 06-04-49486-a and 09-04-01614-a). The work on the content of nutrient elements in plants was supported by the Russian Science Foundation (grant No. 14-16-00137).

* Corresponding author; e-mail: belimov@rambler.ru 
et al. 1995, Cobbett et al. 1998). Likewise, mutants were instruments in identifying metal-specific transport mechanisms or metal-binding proteins involved in tolerance to $\mathrm{Cd}, \mathrm{Cu}, \mathrm{Zn}$, and $\mathrm{Hg}$, such as the metal sensitive $A$. thaliana mutant cupl-1 (Van Vliet et al. 1995). Counteracting the negative effect of $\mathrm{Cd}$ on nutrient uptake by $A$. thaliana roots also contributes to $\mathrm{Cd}$ tolerance of the cadl mutant (Larson et al. 2002). The Cd-tolerant $A$. thaliana mutant $c d r 3-1 D$ is characterized by an increased expression of the AtPDR8/AtPDR 12 transporter, excluding $\mathrm{Cd}$ from roots, and by an increased glutathione (GSH) content (Wang et al. 2011). The A. thaliana mutant $M R C-22$ demonstrated that the root tip senses $\mathrm{Cd}$ and modulates the direction of root growth and root patterning (Watanabe et al. 2010). The significance of phytochelatins, GSH, and antioxidant enzymes in the response to $\mathrm{Cd}$ toxicity was also shown in the Cd-tolerant mutant cadH-5 of Oryza sativa (Shen et al. 2012). The translocation of $\mathrm{Cd}$ from roots to shoots by $\mathrm{Zn}$ and $\mathrm{Mn}$ transporters was demonstrated using the $\mathrm{Cd}$-sensitive mutant of $O$. sativa ( $\mathrm{He}$ et al. 2009). These examples show the fundamental role of mutants and their analysis in dissecting mechanisms contributing to heavy metal tolerance. Most studies used A. thaliana as a genetic model, or addressed the question of hyperaccumulators which exhibit the particular trait of heavy metal tolerance (e.g., Yang et al. 2005, Pollard et al. 2014). Others studied $\mathrm{Cd}$ tolerance in crop species in order to understand the mechanism of $\mathrm{Cd}$ accumulation and to develop strategies to modify it in edible parts (e.g., Shen et al. 2012).

The pea mutant $S G E C d^{t}$ having a single recessive

\section{Materials and methods}

Seeds of the wild-type pea (Pisum sativum L.) line SGE and its Cd-tolerant mutant $S G E C d^{t}$ were surface sterilized and scarified by treatment with $98 \%(\mathrm{~m} / \mathrm{v}) \mathrm{H}_{2} \mathrm{SO}_{4}$ for 30 min, rinsed with sterile water, and germinated on filter paper in Petri dishes at $25^{\circ} \mathrm{C}$ in the dark for three days. Seedlings were transferred to plastic pots (four pots with 10 seeds per genotype) containing $800 \mathrm{~cm}^{3}$ of a nutrient solution $[\mu \mathrm{M}]: \mathrm{KH}_{2} \mathrm{PO}_{4}, 400 ; \mathrm{KNO}_{3}, 1200 ; \mathrm{Ca}\left(\mathrm{NO}_{3}\right)_{2}, 60$; $\mathrm{MgSO}_{4}, 250 ; \mathrm{KCl}, 250 ; \mathrm{CaCl}_{2}, 60 ; \mathrm{Fe}$-tartrate, 10; $\mathrm{H}_{3} \mathrm{BO}_{3}, 2 ; \mathrm{MnSO}_{4}, 4 ; \mathrm{ZnSO}_{4}, 3 ; \mathrm{NaCl}, 6 ; \mathrm{Na}_{2} \mathrm{MoO}_{4}, 0.06$; $\mathrm{CoCl}_{2}, 0,06 ; \mathrm{CuCl}_{2}, 0.06 ; \mathrm{NiCl}_{2}, 0,06 ; \mathrm{pH}$ 5.5. Seedlings were cultivated in growth chambers in the dark (for increasing shoot elongation) for $2 \mathrm{~d}$ and under an irradiance of $400 \mu \mathrm{mol} \mathrm{m} \mathrm{m}^{-2} \mathrm{~s}^{-1}$, a $12-\mathrm{h}$ photoperiod, a minimum/maximum temperature of $18 / 23{ }^{\circ} \mathrm{C}$, and a relative humidity of $60 \%$ for further $2 \mathrm{~d}$. Scions were cut $1 \mathrm{~cm}$ above cotyledons, joined the wedge with rootstocks, and fixed by means of plasticine. Two pots with 10 grafted plants were prepared for each reciprocal graft: the scion SGE/rootstock SGE; scion SGECd//rootstock $S G E C d^{t}$; scion $S G E C d^{t} /$ rootstock SGE; and scion SGE/rootstock $S G E C d^{t}$. The pots were covered with transparent plastic bags to maintain high air humidity and mutation was obtained by treatment of the pea line SGE with ethylmethane sulfonate, and it shows an increased $\mathrm{Cd}$ tolerance and $\mathrm{Cd}$ accumulation (Tsyganov et al. 2007) but a decreased tolerance to and accumulation of $\mathrm{Hg}$ (Belimov et al. 2015, 2016). The mutant locus $c d t$ is localized on the VI linkage group of the pea genetic map, but the sequence of the corresponding gene has not been identified yet (Kulaeva and Tsyganov 2013, Tsyganov et al. 2013). Moreover, SGECd displays higher root sap flow rates both in the presence and in the absence of a toxic $\mathrm{Cd}$ concentration mitigating often encountered negative effects of $\mathrm{Cd}$ on plant water status and transport of water and nutrient elements from roots to shoots (Belimov et al. 2015). Recently, we also reported physiological differences between the SGECd ${ }^{t}$ and the wild type SGE when exposed to other metal ions, e.g., an increased shoot biomass of the mutant in the presence of $400 \mu \mathrm{M} \mathrm{Zn}$, an increased root and shoot biomasses in the presence of $100 \mu \mathrm{M} \mathrm{Fe}$, and an elevated root $\mathrm{Mn}$ or $\mathrm{Zn}$ content in the presence of $400 \mu \mathrm{M} \mathrm{Mn}$ or $\mathrm{Zn}$, compared to SGE plants (Belimov et al. 2016). These multiple alterations suggest that the mutation in the $S G E C d^{t}$ exerts a pleiotropic effect and is involved in regulatory mechanisms which interfere with a short and long distance transports of nutrient elements and water from roots to shoots.

The present report aimed to identify a plant organ, root or shoot, of the SGECd $d^{t}$ mutant which mediates the increased tolerance to $\mathrm{Cd}$ and causes $\mathrm{Cd}$ accumulation. Such knowledge is essential for subsequent addressing molecular mechanisms underlying the response of plants to $\mathrm{Cd}$ toxicity. incubated for $10 \mathrm{~d}$ as described above. During this period, abortive grafts were removed and four successful uniform grafts were left in each pot for further cultivation. Then, the bags were removed and the nutrient solution was changed and supplemented with $1 \mu \mathrm{M} \mathrm{CdCl}_{2}$. Preliminary experiments had established this $\mathrm{Cd}$ concentration as appropriate to ensure survival of the grafted plants with a significant effect on plant growth, and the grafts also showed no differences in plant growth in the absence of $\mathrm{Cd}$. The plants were cultivated for $30 \mathrm{~d}$ with the change of the Cd-supplemented solution every third day. Then, the shoots were cut and the roots were soaked in a $1 \mathrm{mM}$ $\mathrm{Pb}$-citrate solution $(\mathrm{pH} \mathrm{11)}$ for $10 \mathrm{~min}$ and washed in deionized water for desorption of apoplastically bound elements. Then, the plant tissue was dried at room temperature, weighed and stored paper bags for elemental analysis.

To determine the role of nutrient elements $(\mathrm{Ca}, \mathrm{Fe}$, and $\mathrm{Mn}$ ) in differentiation of the Cd-treated SGE and $S G E C d^{t}$, the seeds of both pea genotypes were surface sterilized, scarified, and germinated as described above. The plants (two pots with four plants for each treatment) were cultivated in the same manner as described above 
with differences listed below. To obtain $\mathrm{Ca}, \mathrm{Fe}$, or $\mathrm{Mn}$ deficient conditions, $\mathrm{Ca}\left(\mathrm{NO}_{3}\right)_{2}$ and $\mathrm{CaCl}_{2}, \mathrm{Fe}$-tartrate or $\mathrm{MnSO}_{4}$ were eliminated from the solution. To obtain excess concentrations of these nutrients, the full solution was supplemented with $120 \mu \mathrm{M} \mathrm{CaCl}, 10$ or $100 \mu \mathrm{M}$ Fe-tartrate, and 4 or $400 \mu \mathrm{M} \mathrm{MnSO}_{4}$. Addition of $120 \mu \mathrm{M} \mathrm{Ca}$ and $10 \mu \mathrm{M}$ Fe or $4 \mu \mathrm{M}$ Mn doubled the concentrations of these elements in the full solution resulting in $240 \mu \mathrm{M} \mathrm{Ca}, 20 \mu \mathrm{M} \mathrm{Fe}$, or $8 \mu \mathrm{M} \mathrm{Mn}$, respectively. Treatments with $100 \mu \mathrm{M}$ Fe or $400 \mu \mathrm{M} \mathrm{Mn}$, being sufficient for a growth inhibition of both genotypes (Belimov et al. 2016), had final concentrations of $110 \mu \mathrm{M} \mathrm{Fe}$ or $408 \mu \mathrm{M} \mathrm{Mn}$. The solution was supplemented with $2 \mu \mathrm{M} \mathrm{CdCl}$ in all treatments except of the untreated control. The nutrient solutions were changed at five and nine days after planting. Plants were cultivated for $12 \mathrm{~d}$ after planting in the growth chamber as described above. The plants were dried at room temperature, weighed, and the percentage of $S G E C d^{t}$ biomass to SGE biomass was calculated for roots and shoots.

The roots and shoots of individual plants were ground with a household mill MKM6000 (BOSCH, Berlin, Germany) and digested in a mixture of concentrated $\mathrm{HNO}_{3}$ and $38 \%(\mathrm{v} / \mathrm{v}) \mathrm{H}_{2} \mathrm{O}_{2}$ at $70{ }^{\circ} \mathrm{C}$ using a digester DigiBlock (LabTech, Sorisole, Italy). Content of elements (Ca, Cd, Fe, K, Mg, Mn, Na, P, S, and Zn) in the digested plant samples were determined using an inductively coupled plasma emission spectrometer ICPE-9000 (Shimadzu, Kyoto, Japan) following manufacturer's instructions.

Statistical analysis of the data was performed using the software STATISTICA v. 10 (StatSoft Inc., Tulsa, USA). The Fisher LSD test (one way $A N O V A$ ) was used to evaluate differences between means.

\section{Results}

Both the grafts with $S G E C d^{t}$ rootstocks had higher root and shoot biomasses in the presence of Cd compared with the grafts having SGE rootstocks (Fig. 1A,B). Cadmium content in the roots and shoots of grafts with $S G E C d^{t}$ rootstocks was also higher than in those with the SGE rootstocks (Fig. 1C,D). Only the grafts with the SGE rootstocks showed chlorosis of shoots demonstrating symptoms of Cd toxicity (Fig. 2).

In order to address nutrient homeostasis in the grafted plants as a possible cause for toxicity development, the content of nutrient elements were quantified in the roots. Amounts of macronutrients $\mathrm{K}, \mathrm{P}$, and $\mathrm{Mg}$, as well as of micronutrients $\mathrm{Fe}, \mathrm{Mn}$, and $\mathrm{Zn}$, and also of $\mathrm{Na}$ were higher in the grafts having the $S G E C d^{t}$ rootstocks (Fig. 3) than in the other grafts. Several elements $(\mathrm{K}, \mathrm{Mg}, \mathrm{Na}, \mathrm{P}$, and $\mathrm{Zn}$ ) showed a similar content in the roots and shoots in all the plants. However $\mathrm{Ca}, \mathrm{Fe}$, and $\mathrm{Mn}$ content was higher in the shoots of the grafts having the SGECd rootstocks suggesting that these elements, independently of the scion, were more actively transported by the $S G E C d^{t}$ roots to any grafted shoot. The efficient translocation of these elements likely played a role in $\mathrm{Cd}$

tolerance of the grafts.

To test this hypothesis, both the genotypes were grown in the presence of $\mathrm{Cd}$ and subjected to deficient or excessive concentrations of $\mathrm{Ca}, \mathrm{Fe}$, and $\mathrm{Mn}$. Strongly reduced $\mathrm{Ca}$ content in the nutrient solution had no effect on genotypic differences in shoot biomass (Fig. 4A) and increased a difference in root biomass (Fig. $4 B$ ). On the contrary, high $\mathrm{Ca}$ concentrations decreased the extent of the genotypic differences (Fig. 4A,B) as indicated by the biomass ratio between both the genotypes (Fig. 4C). Significant genotypic differences in shoot and root biomasses were observed after exclusion of $\mathrm{Fe}$ or in the presence of $20 \mu \mathrm{M} \mathrm{Fe}$ in the nutrient solution, however, the supplementation with $110 \mu \mathrm{M} \quad \mathrm{Fe}$ eliminated differences between the Cd-treated genotypes (Fig. 4A,B). In the Mn-free nutrient solution, the root and shoot biomasses of the Cd-treated grafs with the SGECd $d^{t}$ scions were higher than those with the SGE scions. Interestingly, additional $8 \mu \mathrm{M} \mathrm{Mn}$ eliminated the genotypic difference in root biomass. The biomass of both the Cd-treated genotypes in the presence of $404 \mu \mathrm{M}$ Mn was similar.

\section{Discussion}

The results of the experiment with reciprocally grafted plants clearly assign a crucial role of roots in increasing Cd-tolerance and Cd-accumulation of the SGECd mutant. Only the grafts with the mutant rootstock manifested the mutant phenotype. This physiological trait concerns the ability to grow and respond to toxic $\mathrm{Cd}$ (Fig. 1, 2) as firstly reported by Tsyganov et al. (2007) in Pisum sativum. It is likely that an increased Cd tolerance of the $S G E C d^{t}$ roots of this species contributes to an efficient nodulation in the presence of $\mathrm{Cd}$ (Tsyganov et al. 2005), but the observed effect on nodule formation was not related to the expression of genes encoding

glutathione and phytochelatins (Kulayeva and Tsyganov 2015). The findings are also in line with a previous report, which revealed an enhanced water uptake and water transport from roots to shoots in an SGECd $d^{t}$ mutant, both in the absence of $\mathrm{Cd}$ or the presence of $\mathrm{Cd}$ in the nutrient solution. A modified root function in the $S G E C d^{t}$ mutant is evident from an increased root xylem exudation (Belimov et al. 2015). It was concluded that this trait not only alleviates a disturbance in $S G E C d^{t}$ water status caused by $\mathrm{Cd}$ toxicity but also facilitates uptake and translocation of $\mathrm{Cd}$ into the shoot via an enhanced water flow. Indeed, several studies reported negative effects of 
Cd on plant water relations (Poschenrieder and Barcelo 1999, Perfus-Barbeoch et al. 2002, Nedjimi et al. 2009) and a decreased accumulation of heavy metals under water-limited conditions (Leferve et al. 2009, Disante et al. 2014). Those data and the results from this study indicate a close relationship between plant water status and tolerance to and uptake of toxic metals.

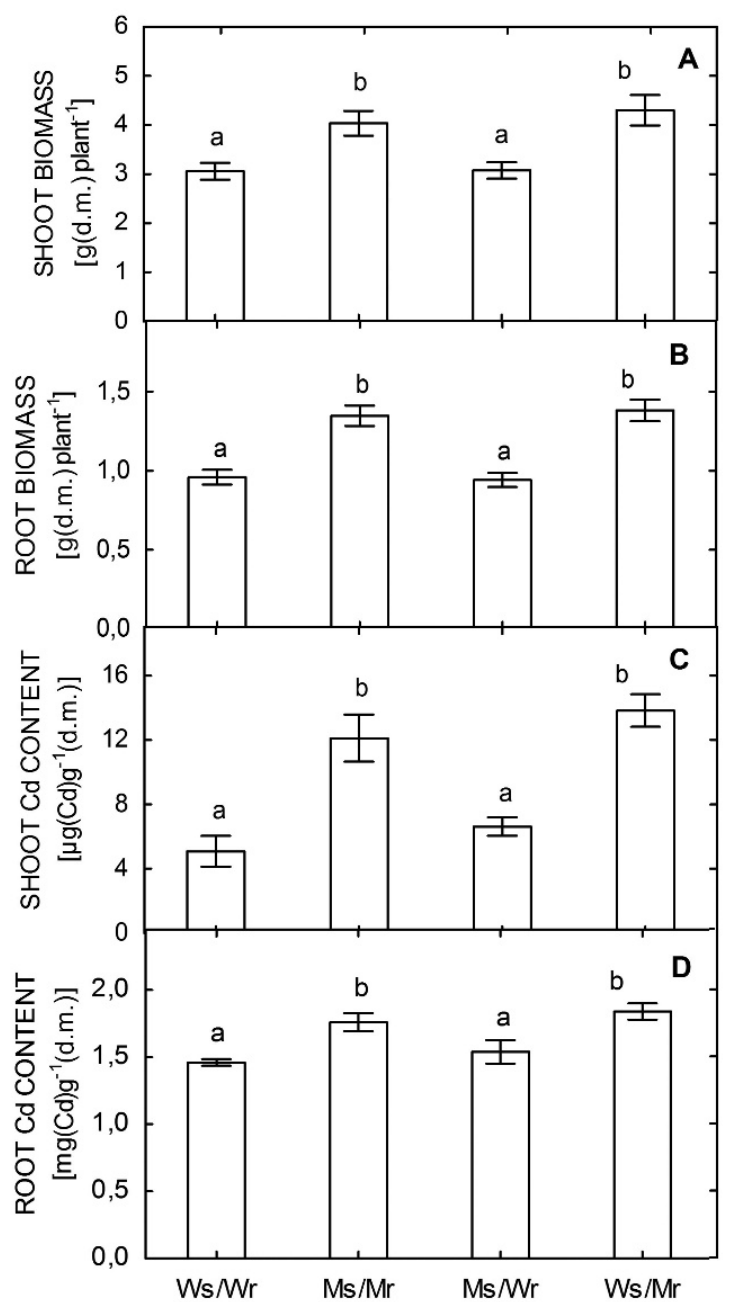

Fig. 1. Shoot $(A)$ and root $(B)$ biomasses and $\mathrm{Cd}$ content in shoots $(C)$ and roots $(D)$ of grafted pea plants grown in the presence of $1 \mu \mathrm{M} \quad \mathrm{CdCl}_{2}$. Reciprocal grafts: scion SGE/rootstock SGE (Ws/Wr); scion $S G E C d^{t} /$ rootstock $S G E C d^{t}$ (Ms/Mr); scion $S G E C d^{t} /$ rootstock SGE (Ms/Wr); scion SGE/rootstock SGECd ${ }^{t}$ (Ws/Mr). Means \pm SEs, $n=8$. Different letters indicate significant differences between treatments (LSD test, $P<0.05)$.

Based on previous results, it was proposed that the Cd-treated $S G E C d^{t}$ mutant is able to incorporate essential nutrient elements more efficiently. Uptake and accumulation concerned in particular $\mathrm{Ca}, \mathrm{Fe}, \mathrm{Mg}, \mathrm{Mn}$, and $\mathrm{S}$ in roots and $\mathrm{B}, \mathrm{Ca}, \mathrm{Mg}, \mathrm{Mn}$, and $\mathrm{Zn}$ in shoots. It was suggested that maintenance of nutrient homeostasis in the $S G E C d^{t}$ mutant counteracts Cd-induced inhibition of nutrient uptake (Tsyganov et al. 2007, Belimov et al.
2016). Toxic Cd concentrations are known to significantly inhibit uptake of mineral elements by roots and thereby affect the ability of plants to maintain nutrient homeostasis. Thus, an efficient nutrient management is considered as an important mechanism of tolerance to toxic metals (Zornoza et al. 2002, Yang et al. 2004, Rodriguez-Serrano et al. 2009, Nazar et al. 2012). This study expands these results by demonstrating an improved availability of several nutrients in the roots of the Cd-treated grafts with a rootstock of the $\mathrm{Cd}$ tolerant $S G E C d^{t}$ mutant. The results indicate the importance of the root for nutrient uptake in the presence of $\mathrm{Cd}$.

At the same time, the grafting experiment shows that the $S G E C d^{t}$ roots efficiently directed three elements, namely $\mathrm{Ca}, \mathrm{Fe}$, and $\mathrm{Mn}$, to a long distance transport to the shoot (Fig. 3). A positive role of $\mathrm{Ca}$ in counteracting toxic effects caused by $\mathrm{Cd}$ was repeatedly reported. Particularly, Ca-deficient Typha latifolia increases Cd accumulation due to $\mathrm{Cd}$-induced expression of the $\mathrm{Ca}^{2+}$-channel gene TlTPC1 encoding a putative membrane transporter (Rodriguez-Hernandez et al. 2015). An increased shoot $\mathrm{Cd}$ content accompanied by growth inhibition has been observed in Ca-deficient rice plants, probably as a result of reduced GSH content and expression of genes related to stress defense (Cho et al. 2012). Addition of excess $\mathrm{Ca}$ to the Cd-supplemented nutrient solution stimulates growth via protection of photosystem II in Phaseolus coccineus leaves (Drazkiewicz and Baszynski 2008), expression of phytochelatin synthase in Latuca sativa roots (He et al. 2005), and a decrease in $\mathrm{Cd}$ content of maize roots (Sterckeman et al. 2011). There is also evidence that addition of $\mathrm{Fe}$ to a nutrient solution decreases uptake and transport of toxic $\mathrm{Cd}$ from roots to shoots in soybean (Cataldo et al. 1983) and increases leaf biomass and chlorophyll content in Cd-treated lettuce plants (Thys et al. 1991). Several reports demonstrated alleviation of $\mathrm{Cd}$ toxicity by treatments of plants with $\mathrm{Mn}$ due to a decrease in $\mathrm{Cd}$ content in maize roots (Palove-Balang et al. 2006), rice leaves (Huang et al. 2017), and roots and leaves of two closely related Mn-hyper-accumulating species Phytolacca americana (Peng et al. 2008) and $P$. acinosa (Liu et al. 2013). The beneficial effect of Mn on Cd-treated rice seedlings is associated with decreases in $\mathrm{Cd}$ content, free proline content, lipid peroxidation, water loss, and activity of ascorbate peroxidase and glutathione peroxidase and $\mathrm{Mn}$ also prevents inhibition of $\mathrm{K}$ and $\mathrm{Mg}$ uptake by roots probably due to a competition between Mn and Cd (Rahman et al. 2016). Our present experiments show that the genotypic differences between the SGE and $S G E C d^{t}$ in their growth response to $\mathrm{Cd}$ significantly depended on $\mathrm{Ca}, \mathrm{Fe}$, or $\mathrm{Mn}$ concentrations in the nutrient solution. The growth advantage of the $S G E C d^{t}$ was maintained or even enhanced under the shortage of these elements, but it decreased or was even eliminated in the excess concentrations (Fig. 4). The results provide new information on the important role of these nutrient elements and the effect of their efficient transportation to the mutant shoot for counteracting $\mathrm{Cd}$ 
toxicity. It should be mentioned that in plants, large families of ion transporters are involved in a local transport of $\mathrm{Ca}, \mathrm{Fe}$, and $\mathrm{Mn}$, as well as in long-distance transport (Pittman 2005, Sharma et al. 2016). In addition, an increased transport of different nutrient elements and also of Cd by the SGECd $d^{t}$ mutant is accompanied by a greater xylem flow induced by root-pressure, which is possibly linked to the function of aquaporins (Belimov et al. 2015). We propose that in the $S G E C d^{t}$ mutant root, key genes involved in regulation of uptake of water and
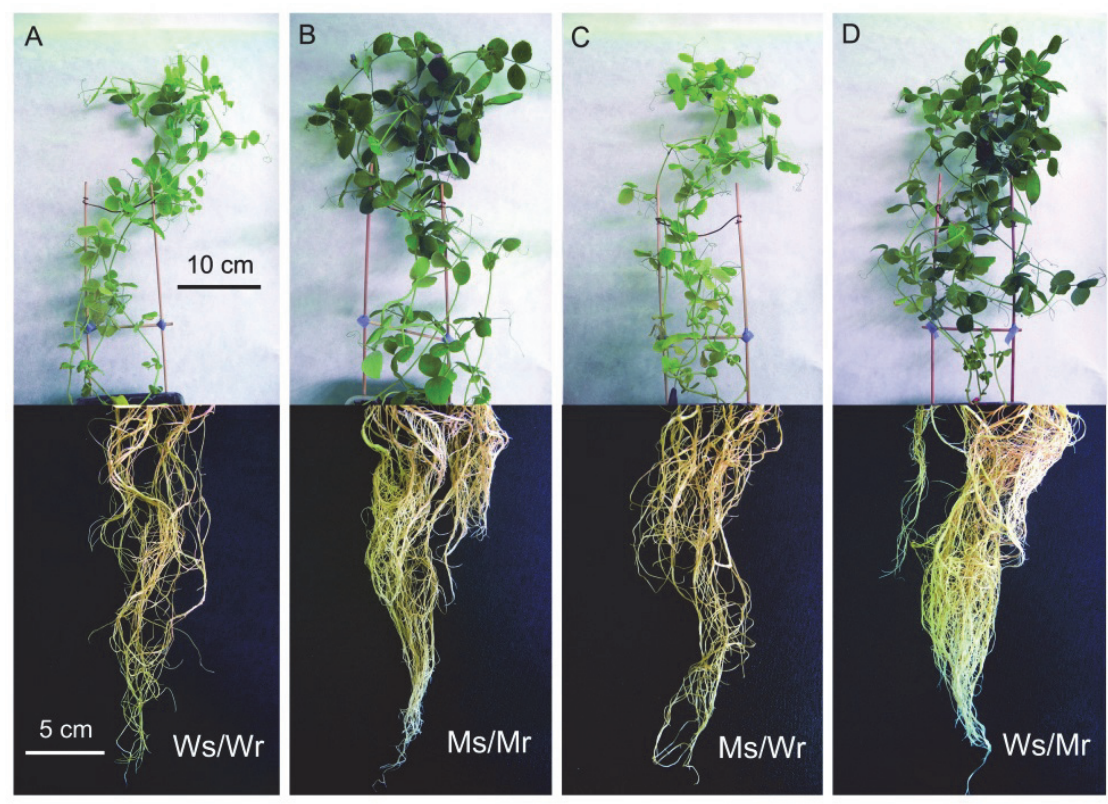

Fig. 2. Images of grafted pea plants grown in the presence of $1 \mu \mathrm{M} \mathrm{CdCl}_{2}$. Reciprocal grafts: $A$ - scion SGE/rootstock SGE (Ws/Wr); $B$ - scion $S G E C d^{t} /$ rootstock $S G E C d^{t}(\mathrm{Ms} / \mathrm{Mr}) ; C$ - scion $S G E C d^{t} /$ rootstock SGE (Ms/Wr); $D$ - scion SGE/rootstock $S G E C d^{t}(\mathrm{Ws} / \mathrm{Mr})$.

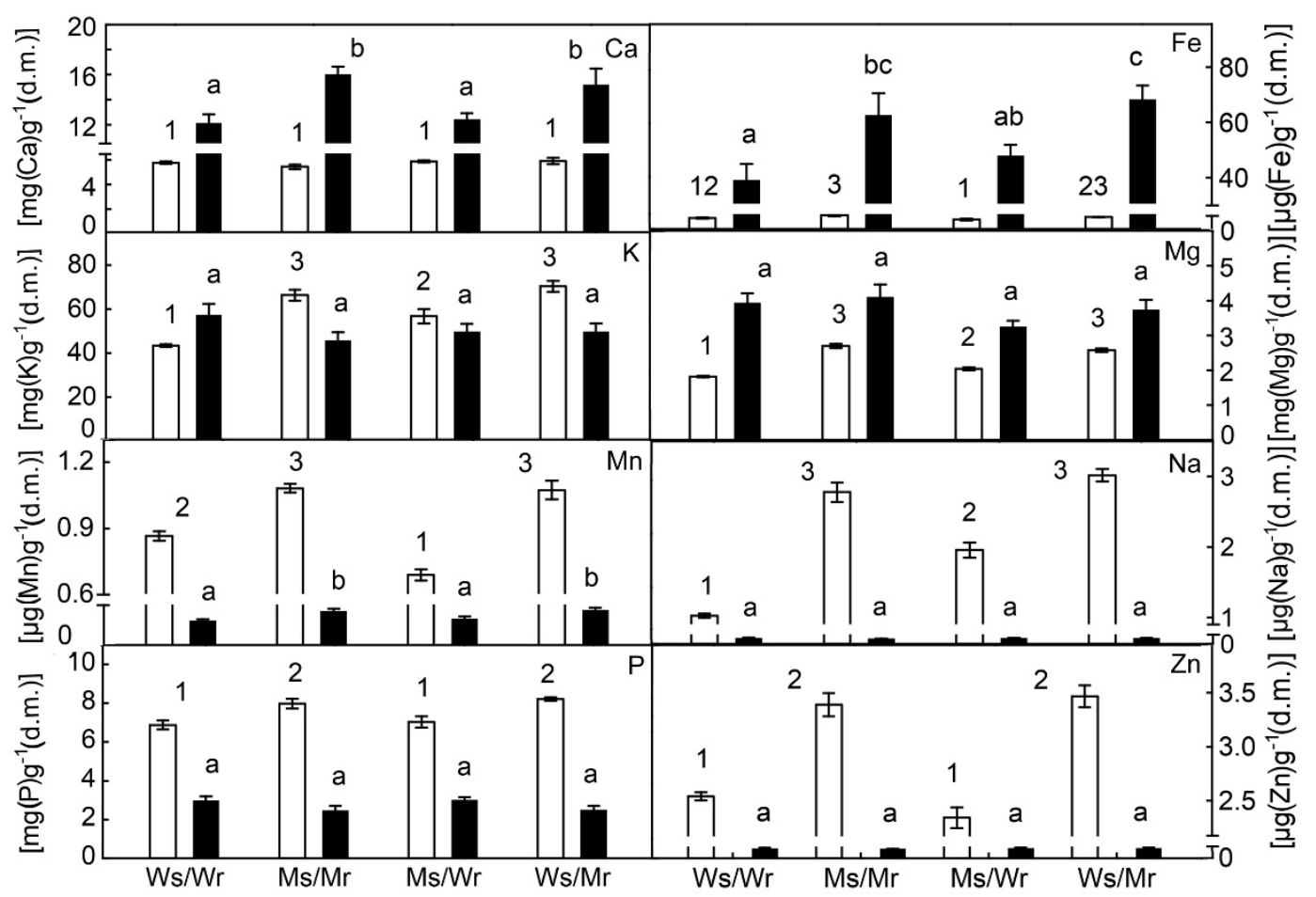

Fig. 3. Content of mineral elements in roots $(\square)$ and shoots $(\mathbf{})$ of grafted pea plants grown in the presence of $1 \mu \mathrm{M} \mathrm{CdCl}$. Reciprocal grafts: scion SGE/rootstock SGE (Ws/Wr); scion $S G E C d^{t} /$ rootstock $S G E C d^{t}(\mathrm{Ms} / \mathrm{Mr})$; scion $S G E C d^{t} /$ rootstock SGE $\left(\mathrm{Ms} / \mathrm{Wr}\right.$ ); scion SGE/rootstock $S G E C d^{t}$ (Ws/Mr). Means $\pm \mathrm{SEs}, n=5$. Different numbers or letters show significant differences between treatments of roots and shoots, respectively (LSD test, $P<0.05$ ). 
transport of nutrient elements were affected and that this modification was responsible for supplying the shoot with nutrients (particularly $\mathrm{Ca}, \mathrm{Fe}$, and $\mathrm{Mn}$ ) enabling active shoot growth and photosynthesis. This, in turn, could ensure normal growth and function of the root via supplying the root with photoassimilates. This hypothesis could be addressed by transcriptome profiling, and experiments in this direction have been recently started.

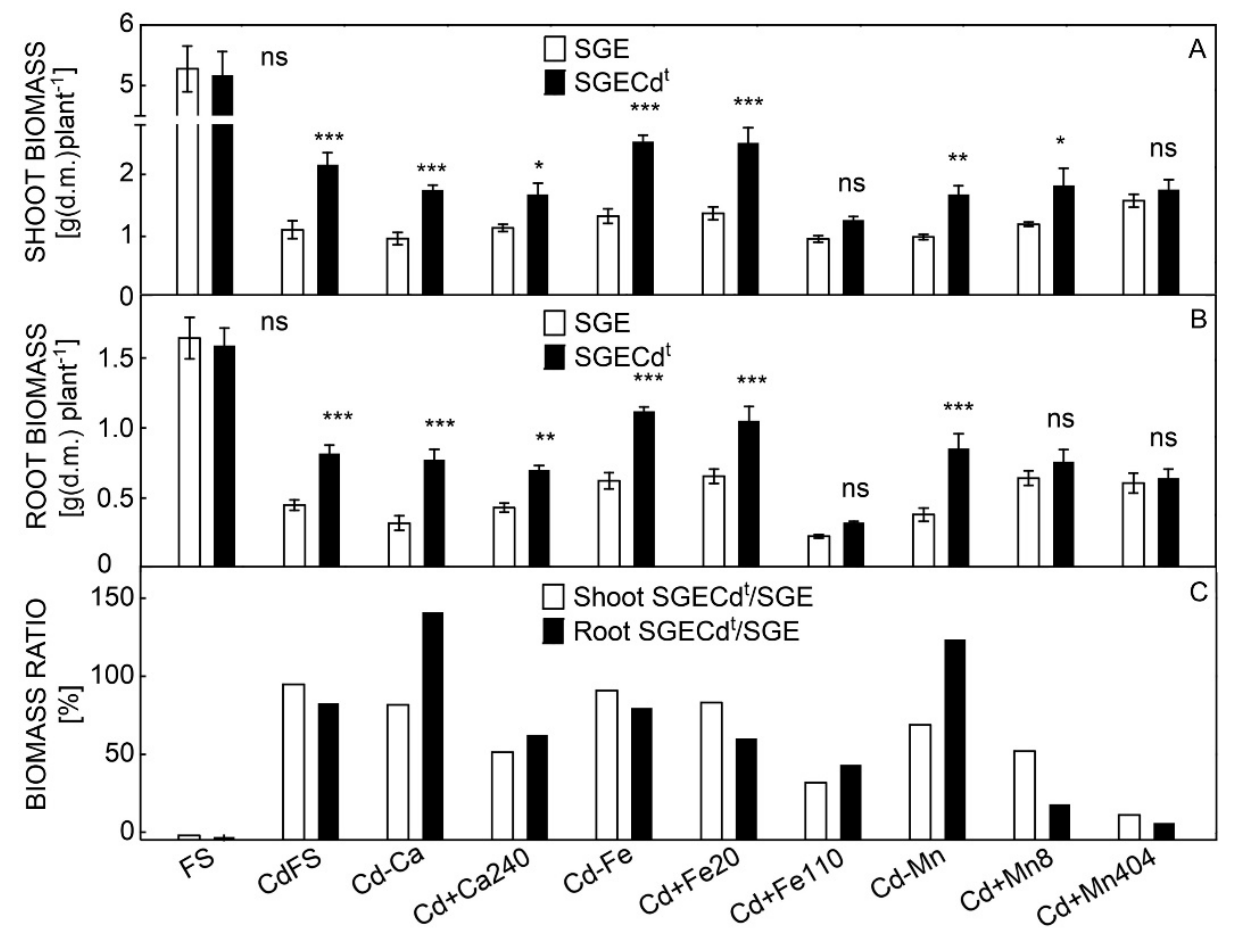

Fig. 4. Shoot $(A)$ and root $(B)$ biomasses and the percentage of biomass of $S G E C d^{t}$ relative to SGE for roots and shoots $(C)$ of nongrafted plants grown under different nutritional conditions. Plants of all treatments, except the Cd-untreated control in the full solution (FS), were grown in the presence of $2 \mu \mathrm{M} \mathrm{CdCl}_{2}$. Treatments: CdFS - Cd-supplemented full solution containing $120 \mu \mathrm{M} \mathrm{Ca}$, $10 \mu \mathrm{M} \mathrm{Fe}$, and $4 \mu \mathrm{M} \mathrm{Mn}$; Cd-Ca - Ca deficient solution; $\mathrm{Cd}+\mathrm{Ca} 240$ - full solution supplemented with $120 \mu \mathrm{M} \mathrm{CaCl}_{2} ; \mathrm{Cd}-\mathrm{Fe}-\mathrm{Fe}$ deficient solution; $\mathrm{Cd}+\mathrm{Fe} 20$ - full solution supplemented with $10 \mu \mathrm{M}$ Fe-tartrate; $\mathrm{Cd}+\mathrm{Fe} 110$ - full solution supplemented with $100 \mu \mathrm{M}$ Fe-tartrate; Cd-Mn - Mn deficient solution; Cd+Mn8 - full solution supplemented with $4 \mu \mathrm{M} \mathrm{MnCl}_{2} ; \mathrm{Cd}+\mathrm{Mn}_{404}-$ full solution supplemented with $400 \mu \mathrm{M} \mathrm{MnCl}_{2}$. Means \pm SEs, $n=8$. Asterisks show significant differences between genotypes (LSD test, $* * * * * *-P<0.05,0.01$, and 0.001 , respectively, ns - nonsignificant differences).

Taken together, the grafting experiments with reciprocal scion/rootstock combinations reveal that tolerance to $\mathrm{Cd}$ as well as the uptake and translocation of $\mathrm{Cd}$ from roots to shoots of the $S G E C d^{t}$ mutant is controlled by the roots. This finding emphasizes the major role of roots as important organs for determining accumulation of toxic heavy metals in plants. It is proposed that the mutation in $S G E C d^{t}$ was related to a regulatory gene that modulated activity of several gene(s) and related molecular transporters. The affected genes were localized and functioned in roots, and they were involved in regulation of uptake and transport to the shoot not only of $\mathrm{Cd}$ but also of water and mineral elements, in particular $\mathrm{Ca}, \mathrm{Fe}$, and $\mathrm{Mn}$. Improved availability of essential nutrients alleviated the Cd stress in the mutants despite the active $\mathrm{Cd}$ uptake by roots and accumulation of it in shoots.

\section{References}

Belimov, A.A., Dodd, I.C., Safronova, V.I., Malkov, N.V., Davies, W.J., Tikhonovich, I.A.: The cadmium tolerant pea (Pisum sativum L.) mutant $S G E C d^{t}$ is more sensitive to mercury: assessing plant water relations. - J. exp. Bot. 66: 2359-2369, 2015.

Belimov, A.A., Malkov, N.V., Puhalsky, J.V., Safronova, V.I., Tikhonovich, I.A.: High specificity in response of pea mutant $S G E C d^{t}$ to toxic metals: growth and element composition. - Environ. exp. Bot. 128: 91-98, 2016.
Cataldo, D.A., Garland, T.R., Wildung, R.E.: Cadmium uptake kinetics in intact soybean plants. - Plant Physiol. 73: 844848, 1983.

Cho, S.-C., Chao, Y.-Y., Kao, C.H.: Calcium deficiency increases $\mathrm{Cd}$ toxicity and $\mathrm{Ca}$ is required for heat-shock induced $\mathrm{Cd}$ tolerance in rice seedlings. - J. Plant Physiol. 169: 892-898, 2012.

Cobbett, C.S., May, M.J., Howden, R., Rolls, B.: The glutathione-deficient, cadmium sensitive mutant, cad2-1, of 
Arabidopsis thaliana is deficient in $\gamma$-glutamylcysteine synthetase. - Plant J. 16: 73-78, 1998.

Disante, K.B., Cortina, J., Vilagrosa, A., Fuentes, D., Hernández, E.I., Ljung, K.: Alleviation of $\mathrm{Zn}$ toxicity by low water availability. - Physiol. Plant. 150: 412-424, 2014.

Dong, J., Mao, W.H., Zhang, G.P., Wu, F.B., Cai, Y.: Root excretion and plant tolerance to cadmium toxicity - a review. - Plant Soil Environ. 53: 193-200, 2007.

Drazkiewicz, M., Baszynski, T.: Calcium protection of PS2 complex of Phaseolus coccineus from cadmium toxicity: in vitro study. - Environ. exp. Bot. 64: 8-14, 2008.

Hasan, S.A., Fariduddin, Q., Ali, B., Hayat, S., Ahmad, A.: Cadmium: toxicity and tolerance in plants. - J. environ. Biol. 30: 165-174, 2009.

He, J.Y., Ren, Y.F., Wang, F.J., Pan, X.B., Zhu, C., Jiang, D.A.: Characterization of cadmium uptake and translocation in a cadmium-sensitive mutant of rice (Oryza sativa L. ssp. japonica). - Arch. Environ. Contam. Toxicol. 57: 299-306, 2009.

He, Z., Li, J., Zhang, H., Ma, M.: Different effects of calcium and lanthanum on the expression of phytochelatin synthase gene and cadmium absorption in Lactuca sativa. - Plant Sci. 168: 309-318, 2005.

Howden, R., Goldsbrough, P.B., Andersen, C.R., Cobbett, C.S.: Cadmium-sensitive, cadl mutants of Arabidopsis thaliana are phytochelatin deficient. - Plant Physiol. 107: 1059-1066, 1995.

Huang, Q.N., An, H., Yang, Y.J., Liang, Y., Shao, G.S.: Effects of $\mathrm{Mn}-\mathrm{Cd}$ antagonistic interaction on $\mathrm{Cd}$ accumulation and major agronomic traits in rice genotypes by different $\mathrm{Mn}$ forms. - Plant Growth Regul. 82: 317-331, 2017.

Kulaeva, O.A., Tsyganov, V.E.: Molecular-genetic basis of cadmium tolerance and accumulation in higher plants. Russ. J. Genet. appl. Res. 1: 349-360, 2011.

Kulaeva, O.A., Tsyganov, V.E.: Fine mapping of a $c d t$ locus mutation that leads to an increase in the tolerance of pea (Pisum sativum L.) to cadmium. - Russ. J. Genet. appl. Res. 3: 120-126, 2013.

Kulaeva, O.A., Tsyganov, V.E.: Gene expression analysis of genes coding key enzymes of cadmium detoxification in garden pea symbiotic nodules. - Russ. J. Genet. appl. Res. 5: 479-485, 2015.

Larsson, E.H., Asp, H., Bornman, J.F.: Influence of prior $\mathrm{Cd}^{2+}$ exposure on the uptake of $\mathrm{Cd}^{2+}$ and other elements in the phytochelatin-deficient mutant, cadl-3, of Arabidopsis thaliana. - J. exp. Bot. 53: 447-453, 2002.

Lefevre, I., Marchal, G., Meerts, P., Correal, E., Lutts, S.: Chloride salinity reduces cadmium accumulation by the Mediterranean halophyte species Atriplex halimus L. Environ. exp. Bot. 65: 142-152, 2009.

Lin, Y.F., Aarts, G.M.: The molecular mechanism of zinc and cadmium stress response in plants. - Cell. Mol. Life Sci. 69: 3187-3206, 2012

Liu, H., Zhang, Y., Chai, T., Tan, J., Wang, J., Feng, S., Liu, G.: Manganese-mitigation of cadmium toxicity to seedling growth of Phytolacca acinosa Roxb. is controlled by the manganese/cadmium molar ratio under hydroponic conditions. - Plant Physiol. Biochem. 73: 144-153, 2013.

Nazar, R., Iqbal, N., Masood, A., Iqbal, M., Khan, R., Syeed, S., Khan, N.A.: Cadmium toxicity in plants and role of mineral nutrients in its alleviation. - Amer. J. Plant Sci. 3: 14761489, 2012.

Nedjimi, B., Daoud, Y.: Cadmium accumulation in Atriplex halimus subsp. schweinfurthii and its influence on growth, proline, root hydraulic conductivity and nutrient uptake. -
Flora 204: 316-324, 2009.

Palove-Balang, P., Kisova, A., Pavlovkin, J., Mistrik, I.: Effect of manganese on cadmium toxicity in maize seedlings. Plant Soil Environ. 52: 143-149, 2006.

Peng, K., Chunling, C., You, W., Lian, C., Li, X., Shen, Z.: Manganese uptake and interactions with cadmium in the hyperaccumulator - Phytolacca Americana L. - J. Hazard. Mater. 154: 674-681, 2008.

Perfus-Barbeoch, L., Leonhardt, L., Vavasseur, A., Forestier, C.: Heavy metal toxicity: cadmium permeates through calcium channels and disturbs the plant water status. - Plant J. 32: 539-548, 2002.

Pittman, J.K.: Managing the manganese: molecular mechanisms of manganese transport and homeostasis. - New Phytol. 167: 733-742, 2005.

Pollard, A.J., Reeves, R.D., Baker, A.J.M.: Facultative hyperaccumulation of heavy metals and metalloids. - Plant Sci. 217-218: 8-17, 2014.

Poschenrieder, C., Barcelo, J.: Water relations in heavy metal stressed plants. - In: Prasad, M.N.V., Hagemeyer, J. (ed.): Heavy Metal Stress in Plants: from Molecules to Ecosystems. Pp. 207-209. Springer-Verlag, Berlin Heidelberg 1999.

Rahman, A., Nahar, K., Hasanuzzaman, M., Fujita, M.: Manganese-induced cadmium stress tolerance in rice seedlings: Coordinated action of antioxidant defense, glyoxalase system and nutrient homeostasis. - Compt. rend. Biol. 339: 462-474, 2016.

Rodriguez-Hernandez, M.C., Bonifas, I., Alfaro-De la Torre, M.C., Flores-Flores, J.L., Banuelos-Hernandez, B., PatinoRodriguez, O.: Increased accumulation of cadmium and lead under $\mathrm{Ca}$ and $\mathrm{Fe}$ deficiency in Typha latifolia: A study of two pore channel (TPC1) gene responses. - Environ. exp. Bot. 115: 38-48, 2015

Rodriguez-Serrano, M., Romero-Puertas, M.C., Pazmino, D.M., Testillano, P.S., Risueno, M.C., Del Rio, L.A., Sandalio, L.M.: Cellular response of pea plants to cadmium toxicity: cross talk between reactive oxygen species, nitric oxide, and calcium. - Plant Physiol. 150: 229-243, 2009.

Sanita di Toppi, L., Gabrielli, R.: Response to cadmium in higher plants. - Environ. exp. Bot. 41: 105-130, 1999.

Sharma, S.S., Dietz, K.J., Mimura, T.: Vacuolar compartmentalization as indispensable component of heavy metal detoxification in plants. - Plant Cell Environ. 39: 1112-1126, 2016.

Shen, G.M., Zhu, C., Shangguan, L.-N., Du, Q.-Z.: The Cdtolerant rice mutant $c a d H-5$ is a high $\mathrm{Cd}$ accumulator and shows enhanced antioxidant activity. - J. Plant Nutr. Soil Sci. 175: 309-318, 2012

Sterckeman, T., Redjala, T., Morel, J.L.: Influence of exposure solution composition and of plant cadmium content on root cadmium short-term uptake. - Environ. exp. Bot. 74: 131139, 2011.

Thys, C., Vanthomme, P., Schrevens, E., De Proft, M.: Interactions of $\mathrm{Cd}$ with $\mathrm{Zn}, \mathrm{Cu}, \mathrm{Mn}$ and $\mathrm{Fe}$ for lettuce (Lactuca sativa L.) in hydroponic culture. - Plant Cell Environ. 14: 713-717, 1991.

Tsyganov, V.E., Belimov, A.A., Borisov, A.Y., Safronova, V.I., Georgi, M., Dietz, K.J., Tikhonovich, I.A.: A chemically induced new pea (Pisum sativum L.) mutant SGECd ${ }^{t}$ with increased tolerance to and accumulation of cadmium. - Ann. Bot. 99: 227-237, 2007.

Tsyganov, V.E., Kulaeva, O.A., Knox, M.R., Borisov, A.Y., Tikhonovich, I.A., Ellis, T.H.N.: Using of SSAP analysis for primary localization of mutation $c d t$ (Cadmium 
tolerance) in pea linkage group VI. - Russ. J. Genet. appl. Res. 3: 152-155, 2013

Tsyganov, V.E., Zhernakov, A.I., Khodorenko, A.V., Kisutin, P.Y., Belimov, A.A., Safronova, V.I., Naumkina, T.S., Borisov, A.Y., Lindblad, P., Dietz, K.J., Tikhonovich, I.A.: Mutational analysis to study the role of genetic factors in pea adaptation to stresses during development its symbioses with Rhizobium and mycorrhizal fungi. - In: Wang, Y.P., Lin, M., Tian, Z.X., Elmerich, C., Newton, W.E. (ed.): Bacterial Nitrogen Fixation, Sustainable Agriculture and the Environment. Pp. 279-281. Springer, Dordrecht 2005.

Van Vliet, C., Anderson, C.R., Cobbett, C.S.: Copper-sensitive mutant of Arabidopsis thaliana. - Plant Physiol. 109: 871878, 1995.

Verkleij, J.A.C., Golan-Goldhirsh, A., Antosiewisz, D.M., Schwitzguebel, J.P., Schroder, P.: Dualities in plant tolerance to pollutants and their uptake and translocation to the upper plant parts. - Environ. exp. Bot. 67: 10-22, 2009.

Wang, Y., Zong, K., Jiang, L., Sun, J., Ren, Y., Sun, Z., Wen, C., Chen, X., Cao, S.: Characterization of an Arabidopsis cadmium-resistant mutant $c d r 3-1 D$ reveals a link between heavy metal resistance as well as seed development and flowering. - Planta 233: 697-706, 2011.

Watanabe, A., Ito, H., Chiba, M., Ito, A., Shimizu, H., Fuji, S., Nakamura, S., Hattori, H., Chino, M., Satoh-Nagasawa, N., Takahashi, H., Sakurai, K., Akagi, H.: Isolation of novel types of Arabidopsis mutants with altered reactions to cadmium: cadmium-gradient agar plates are an effective screen for the heavy metal-related mutants. - Planta 232: 825-836, 2010.

Yang, X., Feng, Y., He, Z., Stoffella, P.J.: Molecular mechanisms of heavy metal hyperaccumulation and phytoremediation. - J. Trace Elem. Med. Bio. 18: 339-353, 2005.

Yang, X.E., Long, X.X., Ye, H.B., He, Z.L., Calvert D.V., Stoffella, P.J.: Cadmium tolerance and hyperaccumulation in a new Zn-hyperaccumulating plant species (Sedum alfredii Hance). - Plant Soil. 259: 181-189, 2004.

Zornoza, P., Vázquez, S., Esteban, E., Fernández-Pascual, M., Carpena, R.: Cadmium-stress in nodulated white lupin: strategies to avoid toxicity. - Plant Physiol. Biochem. 40: 1003-1009, 2002. 